EDITORIAL

\title{
Moments and Open Doors: a Tribute to Mercédès Pavlicevic
}

\section{Brynjulf Stige ${ }^{1 *}$}

1 GAMUT, Grieg Academy-Dept. of Music, University of Bergen, Norway

*brynjulf.stige@uib.no

Published: 1 July 2018

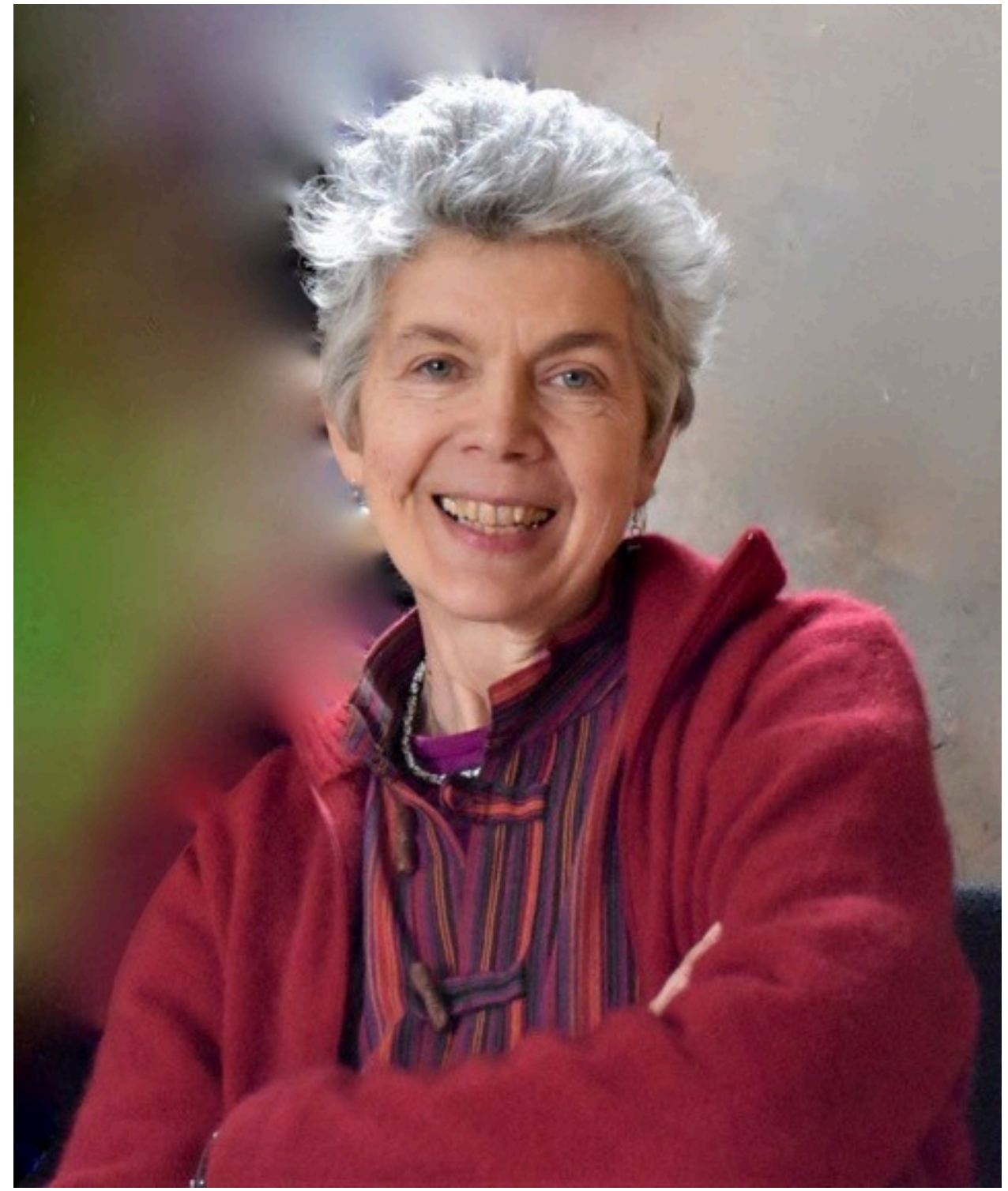

Mercédès Pavlicevic, 1955-2018. Photo: Private 
We publish this issue of Voices just a few days after the funeral of Mercédès Pavlicevic. Our profession and discipline has lost a wonderful person and one of its most articulate voices. The journal Voices has lost one of its pioneers.

In 1999, when I started to explore the possibility of establishing an inclusive and international open access journal of music therapy, together with Carolyn Kenny (another pioneer who we sadly have lost the last few months), one of the first things we decided was that there should be editors from each continent. We did not need a long time to sort out which person in Africa we wanted to invite. At the time, Mercédès Pavlicevic was the head of the first music therapy education program on the African continent. She was a prominent figure in music therapy internationally, and her selfcritical reflexivity about how music therapy is culturally situated fit very well with the vision we had for a new world forum for music therapy. The first paragraph of the first piece Mercédès wrote for the very first issue of Voices, demonstrated this very clearly:

My neighbour at Pretoria University Music Department is Meki Nzwei. Master drummer and music ethnologist, he speaks with passion and authority as befits an elder in Africa. We disagree on many things. And the more I listen to what it is that I disagree with, the more I think he has a point or two. Meki, who hails from Nigeria, maintains that music in Africa is healing, and what is music therapy other than some colonial import? Why is music therapy separate from music-making? Why is it calling itself thus in South Africa, instead of imbibing African music-healing traditions? My blood pressure rises instantly, and I suggest to him that perhaps African music-healing, too, might absorb something from music therapy. This is where Meki and I are at the moment. I think that this is where music therapy in South Africa - and much of Africa - is at the moment (Pavlicevic, 2001a).

Re-reading this today, I feel that this paragraph captures the spirit of Mercédès, both as a person and as a scholar. She was (almost) always intensely engaged in the moment, but with a capacity to step back and reflect. She was (almost) always open, but in ways that did not step back from debate and challenge.

At the time, the editors regularly wrote columns, and the two first columns Mercédès wrote for Voices indeed did have the titles "Moments" and "Open Doors".

In "Moments", Mercédès shared her experience of social-musical situations of particular intensity, in hospital wards and in the community: "These moments are treasures; they are the sacred generosity of this extraordinary Continent. They happen all the time" (Pavlicevic, 2001b). Optimal moments of collaborative musicking were a continuing major interest for Mercédès, which I realized a few years later when I started to work with her in a community music therapy research project including case examples from four different countries (Pavlicevic, 2010). I also realized how being close to Mercédès involved being close to moments of beauty and intensity. These are moments I still treasure.

In the column "Open Doors," Mercédès shared experiences of being drawn to, included in, and excluded from various social-musical situations. Again, she was able to step back and reflect, and to introduce thought-provoking perspectives on what music therapy perhaps could be:

There are multiple analogies, of course. As a music therapist, I think of creating the 'therapeutic space' - and how exclusive or permeable is this? In our minds? Do we allow the client's world - the tangible world, to be in this space? Do we really? I think of music therapy sessions in schools - where children begged me to come to music therapy, because they heard the sessions were fun - and I had to say 'not this time, 'not today', week after week. Until they stopped asking. They remained 'outside'. I think of our different music therapy ideologies and trainings - and how flexible we are in really absorbing and inviting some 'other' approach into our own. I think of our work here in South Africa, and the enormous mind shifts in both ourselves and clients, in order to 'make music' together in a way that 'feels right' to all of us in the room - in fact, not in 'the room' - because one of the things I've learned is that the door needs to be left open. Others might want to join in (Pavlicevic, 2001c).

Thank you, Mercédès, for your strength and capacity to generously share and reflect! We will always be grateful for what you did and who you were, for Voices and for all of us. 
Concluding note: Mercédès worked with Voices for three years. Representatives from the younger generation that she had trained in Pretoria then stepped in, first Andeline Dos Santos and then Helen Oosthuizen, who is still a member of the editorial team. Their contributions honour the work and the values of Mercédès, and invite continued dialogues and discussions about music, health, and social change.

\section{References}

Pavlicevic, M. (2001a). Music therapy in South Africa: Compromise or Synthesis? Voices: A World Forum for Music Therapy, https://dx.doi.org/10.15845/voices.v1i1.43.

Pavlicevic. M. (2001b). Moments. Voices Resources. Retrieved June 19, 2018, from http://testvoices.uib.no/community/?q=fortnightly-columns/2001-moments

Pavlicevic. M. (2001c) Open doors. Voices Resources. Retrieved June 19, 2018, from http://testvoices.uib.no/community/?q= fortnightly-columns/2001-open-doors

Pavlicevic, M. (2010). Let the music work: Optimal moments of collaborative musicing. In B. Stige, G. Ansdell, C. Elefant, \& M. Pavlicevic (Eds.), Where Music Helps. Community Music Therapy in Action and Reflection. Farnham, UK: Ashgate. 